\section{New estimates of fibre in the diet in Britain}

Intakes of dietary fibre or its components have been (inversely) related to the prevalence of several diseases of the intestinal tract, including cancer, and to ischaemic heart disease, obesity, and diabetes. Recent reports on diet and health have accepted that benefit is likely to accrue from an increased intake of dietary fibre, particularly cereal fibre. Only the most recent of these reports has attempted to quantify the amount needed: it recommends that the average intake in Britain should rise from $20 \mathrm{~g}$ to $30 \mathrm{~g} /$ person/day, with a rise to at least $25 \mathrm{~g}$ by $1990 .^{1}$

The estimate of the current intake ${ }^{2}$ was based on household food consumption statistics recorded in 1976 by the Ministry of Agriculture, Fisheries, and Food's National Food Survey and used dietary fibre measurements from McCance and Widdowson's The Composition of Foods. ${ }^{3}$ The component fractions of fibre were mainly those of Southgate et al. ${ }^{4}$ These analyses had been carried out between 1969 and 1976, however, and starch was removed by digestion with takadiastase, which was likely to have been contaminated with enzymes also capable of digesting part of the cellulose and hemicelluloses. As consumption of brown and wholemeal bread, which contains more fibre, has also increased substantially in Britain since 1976, there is a clear need for new and accurate information on the amounts of dietary fibre in foods and of its constituent fractions.

\section{New fractionation technique}

When the Ministry of Agriculture, Fisheries, and Food assumed sole responsibility for revising the British food composition tables the first foods to be analysed included 103 types of bread and other cereal products and 35 meat products which contain cereals. The method for measuring fibre was still based on the original fractionation technique of Southgate, ${ }^{4}$ but it had been improved in that a mixture of amyloglucosidase and $\alpha$-amylase was used to break down starch; this was followed by digestion with hot $5 \%$ sulphuric acid for one hour and then with $72 \%$ sulphuric acid overnight at $4^{\circ} \mathrm{C}$ Sugars and uronic acids in these hydrolysates were measured colorimetrically, and the final residue (lignin) was weighed. Dietary fibre was taken as the sum of the lignin, cellulose, and non-cellulosic polysaccharides weighed during this fractionation method.

The most important consequences of the modifications of the fractionation technique were that more pentose and hexose non-cellulosic polysaccharides were found and a greater residue of lignin remained. For example, sliced white bread now appears to contain $4.1 \mathrm{~g}$ fibre $/ 100 \mathrm{~g}$ compared with the previous estimate of $2 \cdot 7 \mathrm{~g} / 100 \mathrm{~g}^{3}$ This report measures the effects of the new analyses on the average intake of dietary fibre and the major components of this fibre in the diet of the nation as a whole. (Full details of the methods used and of the fibre contents of individual foods will be published elsewhere.)

\section{Average intake of fibre and its components}

The table compares the new intake of dietary fibre with the values

Effect of new analyses on calculations of average intake of dietary fibre ( $g /$ person day) in Britain in 1982

\begin{tabular}{|c|c|c|c|}
\hline & \multicolumn{2}{|c|}{ Intakes ( $\mathrm{g} /$ person/day) using: } & \multirow[b]{2}{*}{ Change $(\%)$} \\
\hline & Original analyses* & New analyses & \\
\hline $\begin{array}{l}\text { Bread and flour } \\
\text { Other cereals } \\
\text { Meat products } \\
\text { Fruit } \\
\text { Vegetables } \\
\text { Miscellaneous }\end{array}$ & $\begin{array}{l}5.2 \\
3.0 \\
0.5 \\
1.4 \\
9 \cdot 2 \\
0.5\end{array}$ & $\begin{array}{c}\text { Food groups } \\
7 \cdot 1 \\
3 \cdot 3 \\
0.7 \\
1 \cdot 4^{*} \\
9 \cdot 2^{*} \\
0.5^{*}\end{array}$ & $\begin{array}{r}+37 \\
+10 \\
+40\end{array}$ \\
\hline Total dietary fibre & $19 \cdot 8$ & $22 \cdot 2$ & +12 \\
\hline $\begin{array}{l}\text { Non-cellulose polysaccharides } \\
\text { Hexoses } \\
\text { Pentoses } \\
\text { Uronic acids } \\
\text { Cellulose } \\
\text { Lignin }\end{array}$ & $\begin{array}{ll} & 13 \cdot 2 \\
2 \cdot 2 & \\
2 \cdot 7 & \\
2 \cdot 2 & 5 \cdot 6 \\
& 1 \cdot 0\end{array}$ & 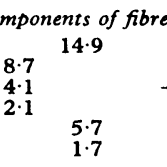 & $\begin{array}{r}e \\
+6 \\
+52 \\
+5\end{array}$ \\
\hline Total dietary fibre & $19 \cdot 8$ & $22 \cdot 2$ & +12 \\
\hline
\end{tabular}

-From McCance and Widdowson's The Composition of Foods's and Southgate et al." that would have been recorded using earlier analyses. ${ }^{34}$ Both amounts are based on the consumption of food recorded in the National Food Survey of 1982. The main effects are that the total intake is now $22.2 \mathrm{~g}$ and not $19.8 \mathrm{~g} /$ person/day, which may be compared with the recent recommendation for an increase to $25 \mathrm{~g} /$ person/day by $1990,{ }^{1}$ and that the epidemiologically important pentose fraction of the non-cellulosic polysaccharides and the intake of lignin have increased by $52 \%$ and $70 \%$ respectively. Despite the continued decline in the consumption of white bread, the contribution of the nutritionally important cereal fibre to the total has also risen by $28 \%$.

We thank-Mrs P A Jackson and Dr J R Cooke, both of the Laboratory of the Government Chemist, for help with calculating the fibre components of the foods and for helpful discussions.

' National Advisory Committee on Nutrition Education. Proposals for nutritional guidelines for health education in Britain. London: Health Education Council, 1983.

${ }^{2}$ Bingham S, Cummings JH, McNeil NI. Intakes and sources of dietary fibre in the British population. Am F Clin Nutr 1979;32:1313-9.

${ }^{3}$ Paul AA, Southgate DAT. McCance and. Widdowson's the composition of foods. 4th ed. London: HMSO, 1978.

- Southgate DAT, Bailey D, Collinson E, Walker AF. A guide to calculating intakes of dietary fibre. $₹$ Hum Nutr 1976;30:303-13.

${ }^{5}$ Ministry of Agriculture, Fisheries, and Food. Household food consumption and expenditure: 1982. London: HMSO (in press).

(Accepted 11 April 1984)

Ministry of Agriculture, Fisheries, and Food, London SW1P 2AE

R W WENLOCK, BSC, FRSH, nutritionist

D H BUSS, PHD, FIEST, head of mutrition branch

Laboratory of the Government Chemist, London SE1 9NQ

IRENA B AGATER, BSC, analytical chemist

Correspondence to: Mr R W Wenlock, Food Science Division, Ministry of Agriculture, Fisheries, and Food, Great Westminster House, Horseferry Road, London SWIP 2AE.

\section{Nebuhaler versus nebuliser in children with acute asthma}

A major problem for children using standard metered aerosols is coordinating inspiration with actuating the aerosol. Moderate to severe airways obstruction further limits the dose reaching the airways. Spacer devices attached to metered aerosols improve delivery of drugs. ${ }^{1}$ In adults with chronic asthma a $750 \mathrm{ml}$ pear shaped attachment (Nebuhaler) provided equal bronchodilatation to a nebuliser when about $25 \%$ of the dose was used. ${ }^{2}$ In adults with acute asthma the Nebuhaler was as effective as the nebuliser when the same dose was used. $^{3}$

This study aimed at determining whether a Nebuhaler with a conventional metered aerosol was an acceptable alternative to wet nebuliser treatment in acute asthma in childhood.

\section{Patients, methods, and results}

We studied 28 children (18 boys, 10 girls) aged 3-13 presenting to the accident and emergency department of this centre with acute asthma. All parents gave informed consent. Children who had received bronchodilator treatment with an aerosol within two hours before presentation were excluded.

The children were randomly allocated to two groups receiving $1 \%$ terbutaline sulphate either through a Hudson nebuliser attached to an air cylinder (flow rate $61 /$ minute) or by metered dose aerosol through a Nebuhaler. The nebuliser solution was made up to $2 \mathrm{ml}$ with saline and nebulised completely. Doses were based on weight ${ }^{4}$ : children weighing under $20 \mathrm{~kg}$ received $0.25 \mathrm{ml}(2.5 \mathrm{mg})$ through a nebuliser or five puffs $(1.25$ $\mathrm{mg}$ ) through a Nebuhaler; those weighing over $20 \mathrm{~kg}$ received $0.5 \mathrm{ml}(5 \mathrm{mg})$ through a nebuliser or 10 puffs $(2.5 \mathrm{mg})$ through a Nebuhaler. The Nebuhaler was used for one minute to ensure complete intake of the dose.

All patients were evaluated clinically at 0,15 , and 30 minutes after receiving terbutaline by $\mathrm{MF}$, who measured clinical variables useful in assessing the severity of asthma ${ }^{5}$-namely, dyspnoea, wheeze, muscle contraction, supraclavicular excavation, thoracoabdominal paradox, pulse, respiratory rate, and 
pulsus paradoxus. Variables were assessed on a scale of 0-4 and a total score obtained. Peak expiratory flow rate was measured with Wright's mini peak flow meter in children able to cooperate (six in the nebuliser and 11 in the Nebuhaler groups). The best of three attempts was recorded and expressed as a percentage of the value predicted for sex and height.

Results were analysed using Wilcoxon's signed rank test and paired or unpaired $t$ tests when appropriate.

The sex distribution in the two groups were the same, but mean ages were 6.1 years in the nebuliser and 9.1 years in the Nebuhaler group $(p<0.005)$ The figure shows the mean clinical scores and peak expiratory flow rates. There were no significant differences between the groups at any time but both groups showed appreciable improvements at 15 and 30 minutes
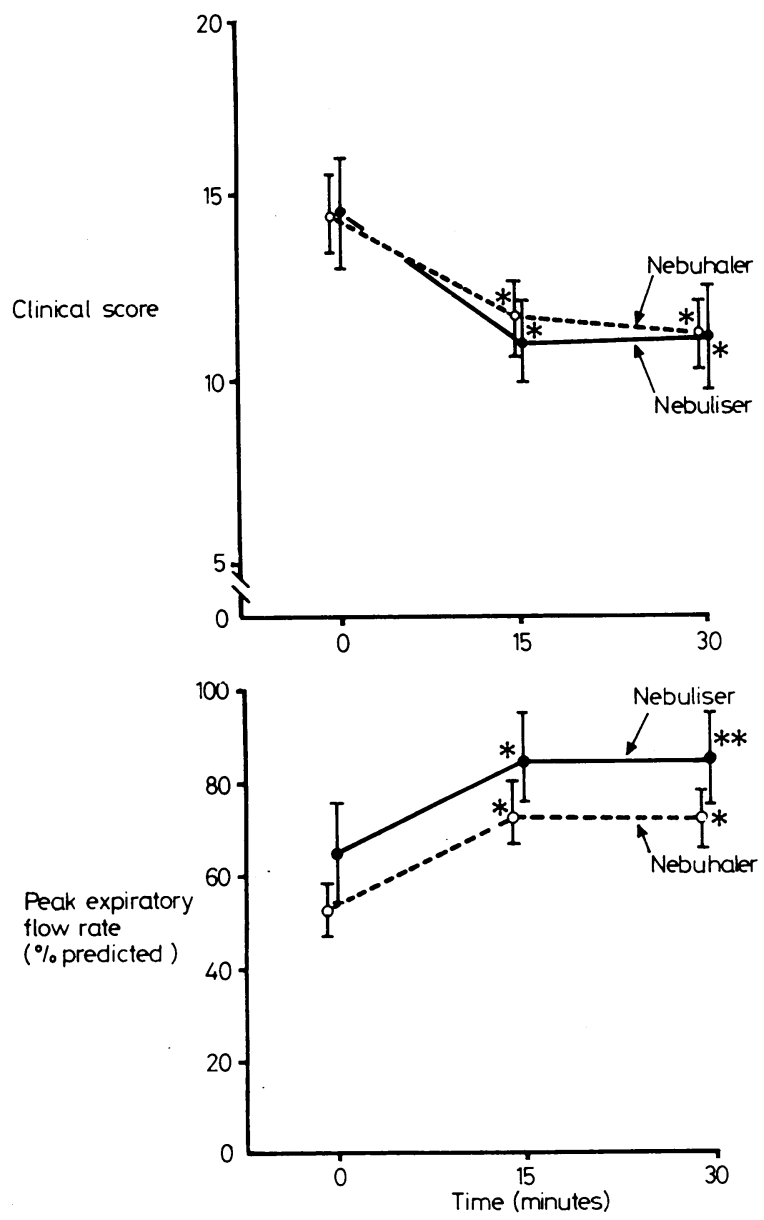

Mean (SE) clinical scores and peak expiratory flow rates in groups using a nebuliser and Nebuhaler. There was a significant reduction in clinical scores $(* \mathrm{p}<0.01)$ and improvement in peak expiratory flow rates $\left({ }^{*} p<0.01,{ }^{* *} p<0.02\right)$ in both groups but no significant differences between groups.

One child from the Nebuhaler group and three from the nebuliser group required admission to hospital despite initial treatment. Four children who used the Nebuhaler, including the one admitted, had difficulty triggering the valve, which was related to a greater degree of airways obstruction. On the other hand, four patients who had repeatedly used aerosols at home with little improvement responded well to the Nebuhaler.

\section{Comment}

The results indicate that in children with acute asthma equal bronchodilatation can be achieved with Nebuhalers and nebulisers. Younger children and patients with severe airways obstruction, however, had problems with the Nebuhaler, probably because they could not produce sufficient flow rates to trigger the valve. The manufacturers are now investigating this. We conclude that, apart from this limitation, the Nebuhaler is an acceptable and cheaper alternative to wet nebuliser treatment of acute asthma in childhood.

We thank Astra Pharmaceuticals for providing the Nebuhaler and terbutaline and for financial support, and Mrs Gwen Maharaj for secretarial help.

${ }^{1}$ Newman SP, Moren F, Pavia D, Little F, Clark SN. Deposition of pres- surised suspension aerosols inhaled through extension devices. Am Rev Respir Dis 1981;124:317-20.

- Birk-Madsen E, Bundgaard A, Hidinger KG. Cumulative dose response study comparing terbutaline pressurised aerosol administered via a pear shaped spacer and terbutaline in a nebulised solution. Eur $\mathcal{F}$ Clin Pharmacol 1982;23:27-30.

${ }^{3}$ Morgan MDL, Singh BV, Frame MH, Williams SJ. Terbutaline aerosol given through pear spacer in acute severe asthma. $\mathrm{Br}$ Med $\mathcal{F} 1982 ; 285$ : 849-50.

+ Ritchie D, Erben A, McLennan L, Landau LI, Phelan PD. Dose of terbutaline respiratory solution in children with asthma. NZ Med f 1979; 89:332-4.

sommey JOO, Levison H. Physical signs in childhood asthma. Pediatrics 1976;58:537-41.

(Accepted 16 February 1984)

Department of Paediatrics, Westmead Centre, Westmead 2145, Australia

M FREELANDER, $M B, B S$, paediatric registrar

P P VAN ASPEREN, MB, FRACP, staff paediatrician (respiratory diseases)

Correspondence to: Dr P P Van Asperen.

\section{Tuberculosis of the breast}

Tuberculosis of the breast is rare, presenting as either a breast lump or an abscess and often associated with evidence of active tuberculosis elsewhere in the body, particularly cervical lymphadenopathy or active pulmonary tuberculosis. ${ }^{12}$ We report on five Asian women seen at this hospital over six months who were found to have tuberculosis of the breast.

\section{Case reports}

Case 1-A 48 year old woman from Bangladesh presented with a four month history of a painful red lump in the right breast. At operation an abscess was drained and breast tissue biopsied. The pus grew Mycobacterium tuberculosis; histological examination showed caseating granulomas with giant cells.

Case 2-A 43 year old Malaysian nurse presented with a three week history of a painless lump in the right breast. Clinically this was thought to be a fibroadenoma, but histological examination showed an enlarged lymph node with areas of caseating necrosis and Langhans' giant cells.

Case 3-A 27 year old Indian woman presented with a one week history of fever and a painful swelling of the right breast. The right breast was tender, red, and indurated. An abscess was incised and pus drained, which was sterile on culture. The pus was not cultured for tuberculosis as this was not suspected. The abscess recurred despite treatment with ampicillin and flucloxacillin. She became feverish again and developed erythema nodosum. Two further drainage procedures were required. Histological examination showed chronic inflammatory tissue with epithelioid granulomas and Langhans' giant cells. The induration improved slowly with antituberculous chemotherapy.

Case 4-A 65 year old Indian woman presented with a one month history of a painful swelling overlying the upper part of the left breast; she was found in addition to have an enlarged left supraclavicular lymph node. At operation an abscess was drained; $M$ tuberculosis was cultured from the pus, and histological findings were typical of tuberculosis.

Case 5-A 53 year old Indian woman presented with a three week history of a painful lump in the left breast. A thick walled abscess was drained. Histological findings were typical of tuberculosis, with caseating granulomas and giant cells. The pus was not cultured for tuberculosis.

\section{Comment}

Previous reports have suggested that active tuberculosis is present in other sites in the body in $25-84 \%$ of patients with tuberculosis of the breast ${ }^{3}{ }^{4}$ but that evidence of previous tuberculosis elsewhere is

Findings in five women with unsuspected tuberculosis of the breast

\begin{tabular}{|c|c|c|c|c|c|}
\hline \multirow[b]{2}{*}{$\begin{array}{l}\text { Case } \\
\text { No }\end{array}$} & \multirow[b]{2}{*}{$\begin{array}{c}\text { Age } \\
\text { (years) }\end{array}$} & \multirow[b]{2}{*}{$\begin{array}{l}\text { Clinical } \\
\text { finding }\end{array}$} & \multicolumn{3}{|c|}{ Result of: } \\
\hline & & & $\begin{array}{l}\text { Tuberculin } \\
\text { test }\end{array}$ & $\begin{array}{l}\text { Microbiological } \\
\text { examination }\end{array}$ & $\begin{array}{l}\text { Chest } x \text { ray } \\
\text { examination }\end{array}$ \\
\hline $\begin{array}{l}1 \\
2 \\
3 \\
4 \\
5\end{array}$ & $\begin{array}{l}48 \\
43 \\
27 \\
65 \\
53\end{array}$ & $\begin{array}{l}\text { Abscess } \\
\text { Lymph node } \\
\text { Abscess } \\
\text { Abscess } \\
\text { Abscess }\end{array}$ & $\begin{array}{l}\text { Strongly positive } \\
\text { Not done } \\
\text { Strongly positive } \\
\text { Not done } \\
\text { Not done }\end{array}$ & $\begin{array}{l}\text { Culture positive } \\
\text { Not done } \\
\text { Not done } \\
\text { Culture positive } \\
\text { Not done }\end{array}$ & $\begin{array}{l}\text { Hilar calcification } \\
\text { Hilar calcification } \\
\text { Normal } \\
\text { Hilar calcification } \\
\text { Hilar calcification }\end{array}$ \\
\hline
\end{tabular}

